\title{
Penegakan Hukum terhadap Pencemaran Lingkungan di Sungai Cikijing, Jawa Barat Akibat Aktivitas Industri Tekstil PT. Kahatex
}

\author{
Agung Kurniawan Sihombing ${ }^{1}$
}

\begin{abstract}
Abstrak
Hak untuk mendapatkan lingkungan hidup yang baik dan sehat merupakan hak fundamental manusia yang diatur dalam Undang-undang Dasar 1945 dan peraturan perundang-undangan di bawahnya. Di sisi lain, negara membutuhkan pembangunan sebagai upaya dalam memajukan negaranya. Sayangnya, kedua hal ini sulit berjalan beriringan secara optimal. Hal ini dikarenakan pemenuhan hak atas lingkungan yang baik dan sehat sering kali terhambat oleh aktivitas industri yang tidak bertanggung jawab. Contohnya, hal ini dapat dilihat pada kasus pembuangan limbah tekstil PT. Kahatex di Kabupaten Bandung yang telah mencemari Sungai Cikijing di Rancaekek, Jawa Barat. PT. Kahatex masih terlihat melaksanakan aktivitasnya yang berdampak pada pencemaran lingkungan, meski izin pembuangan limbahnya telah dicabut. Lebih lanjut, Bupati Sumedang tidak berani menghentikan operasi perusahaan tersebut mengingat jumlah karyawan PT. Kahatex yang terancam kehilangan pekerjaan. Oleh karena itu, tulisan ini bertujuan untuk menganalisis permasalahan lingkungan yang ada serta memberikan saran terhadap penegakan hukum yang sebaiknya dilakukan.
\end{abstract}

Kata kunci: Cikijing, industri, lingkungan, penegakan hukum, PT. Kahatex

\begin{abstract}
The right to a good and healthy environment is a fundamental right which is regulated in the Indonesian Constitution and the regulations below it. On the other hand, the state needs development to make the people prosperous. However, these two concepts are difficult to go hand in hand optimally. This due to the right to a good and healthy environment is often hampered by irresponsible industrial activities. For example, this could be seen in textile waste disposal by PT. Kahatex in Bandung Regency which has polluted the Cikijing River in Rancaekek, West Java. PT. Kahatex was still carrying out its activities which impacted in polluting the environment, However, whereas the waste disposal permit has been revoked. Moreover, The Sumedang Regent did not have the courage to stop the company's operations, considering the number of employees from PT Kahatex is threatened to be jobless. Therefore, this paper aims to analyze existing environmental problems and suggests recomendation for the law enforcement.
\end{abstract}

Keywords: Cikijing, industry, environment, law enforcement, PT. Kahatex

${ }^{1}$ Penulis adalah Mahasiswa Program Sarjana di Fakulltas Hukum Universitas Padjadjaran. 
Penegakan Hukum Terhadap Pencemaran Lingkungan di Sungai Cikijing, Jawa Barat Akibat Aktivitas Industri Tekstil PT. Kahatex

\section{Pendahuluan}

Hak atas lingkungan hidup yang baik dan sehat merupakan bagian dari hak asasi manusia (HAM) yang diatur dalam Pasal 28 H Undang-Undang Dasar Negara Republik Indonesia Tahun 1945. ${ }^{2}$ Hal ini memiliki konsekuensi bahwa negara harus memastikan terpenuhinya hak atas lingkungan hidup dengan kualitas minimal yang memungkinkan terwujudnya kehidupan yang bermartabat dan sejahtera dengan penegakan hukum yang ba$i^{3}{ }^{3}$ Salah satu upaya penegakan hukum yang penting di bidang lingkungan ialah adanya sanksi terhadap pelanggarannya. Sanksi ini dapat berbentuk sanksi pidana, sanksi perdata, dan sanksi administrasi. ${ }^{4}$

Di sisi lain, sebagai negara berkembang, Indonesia harus mendorong laju pembangunannya dengan aktivitas industrial. ${ }^{5}$ Sayangnya, kegiatan industri menjadi salah satu sektor pembangunan yang sangat berpotensi merusak lingkungan hidup. Hal ini juga ditandai oleh banyaknya kasus perusahaan industri yang diberikan sanksi denda dengan jumlah yang besar akibat kerusakan lingkungan yang mereka sebabkan. ${ }^{6} \mathrm{Ke}-$ rusakan yang dihasilkan oleh industri-industri tersebut dapat berupa polusi udara, polusi air, dan polusi tanah yang masing-masing memiliki dampak berbahaya dan kesulitan upaya penanganannya masing-masing. ${ }^{7}$

Melihat besarnya potensi pencemaran lingkungan oleh aktivitas industri, Valentino Darsono mengatakan, apabila hal ini tidak mendapat perhatian yang serius, maka antara industri dan lingkungan hidup tidak berjalan seiring, akan menimbulkan kesan bahwa semakin maju industri maka semakin rusak lingkungan hidup. ${ }^{8}$ Permasalahan tersebut tercermin pada tindakan PT. Kahatex yang mence-

${ }^{2}$ Indonesia (a), Undang-Undang Dasar Negara Republik Indonesia Tahun 1945, ps. 28 H.

${ }^{3}$ Junior B. Gregorius, “Hak Asasi Manusia (HAM) Atas Lingkungan Hidup (Suatu Rekfleksi Sosio-Yuridis atas Implementasi Penyelesaian Sengketa Lingkungan)", Jurnal Hukum dan Pembangunan Tahun ke-39, No. 23, (2009), hlm. 288.

${ }^{4}$ Harry Agung Ariefianto, "Penerapan Sanksi Administrasi Pencemaran Lingkungan Hidup Akibat Kegiatan Industri (Studi Kasus Di CV. Slamet Widododi Semarang)", Unnes Law Journal, Vol. 4, No. 1, (2015), hlm. 81.

${ }^{5}$ Yeni Nuraeni, “Dampak Perkembangan Industri Pertambangan Nikel Terhadap Kondisi Sosial, Ekonomi Dan Budaya Masyarakat", Seminar Nasional Edusainstek FMIPA UNIMUS, 2018, hlm. 13.

${ }^{6}$ Restu Diantina Putri, "11 Perusahaan Perusak Lingkungan Rugikan Negara Rp18 Triliun Baca selengkapnya di artikel "11 Perusahaan Perusak Lingkungan Rugikan Negara Rp18 Triliun", Tirto.id, 2019, https:// tirto.id/dgZ6"https:// tirto.id/11-perusahaan-perusak-lingkungan-rugikan-negara-rp18-triliun-dgZ6, diakses tanggal 6 Oktober 2020.

${ }^{7}$ Ita Rustiati Ridwan, "Dampak Industri Terhadap Lingkungan Dan Sosial”, Jurnal Geografi Gea, Vol., No. 2, (2010), hlm. 4.

${ }^{8}$ Valentinus Darsono, Pengantar Ilmu Lingkungan, (Yogyakarta: Universitas Atma Jaya Yogyakarta, 
mari sungai Cikijing sejak lama, sehingga berakibat dengan kerugian masyarakat setempat, seperti mengganggu aktivitas sehari-hari dan menyebabkan kegagalan panen karena rusaknya lahan. ${ }^{9}$ Bahkan, pada Februari 2020 lalu, Dedi Kurniawan selaku Ketua Dewan Daerah Walhi Jawa Barat mengatakan bahwa bau banjir di Rancaekek yang terjadi di bulan tersebut dipengaruhi oleh limbah pabrik PT. Kahatex yang dibuang saat musim hujan. ${ }^{10}$

PT. Kahatex merupakan industri tekstil yang terletak di Jalan Raya Rancaekek Km.23 No. 25, Kabupaten Sumedang, Provinsi Jawa Barat. Perusahaan ini berkembang menjadi sebuah pabrik yang besar, sebagai produsen terlengkap mulai dari pembuatan serat, pemintalan, pertenunan, penyempurnaan, dan pembuatan pakaian jadi (garmen) dengan mempekerjakan puluhan ribu karyawan. ${ }^{11}$ Aktivitas industri ini mengakibatkan penurunan kualitas lingkungan se- tempat yang dapat dilihat dari indikator pencerna seperti adanya bau menyengat dan warna hitam pekat air limbah yang dibuang ke Sungai Cikijing. Pasalnya, air limbah ini paling banyak berasal dari limbah cair proses industri seperti bahan pewarna tekstil yang dihasilkan oleh kegiatan produksi garmen. ${ }^{12}$

Sungai Cikijing sendiri berada di Kabupaten Bandung, melintasi empat kawasan desa, yaitu Desa Jelegong, Desa Linggar, Desa Sukamulya dan Desa Bojongloa, di mana keempat Desa tersebut adalah kawasan pertanian lahan basah dan kawasan permukiman. Selain itu, masyarakat juga menggunakan air sungai tersebut untuk keperluan sehari-hari seperti mandi, cuci dan memasak. Sungai ini melewati dua kabupaten, yakni Kabupaten Sumedang dan Kabupaten Bandung. ${ }^{13}$ Hal tersebut menyebabkan pembuangan limbah yang dilakukan di sekitar daerah Rancaekek ini pun meng-

1995), hlm. 54.

${ }^{9}$ Dila Nashear, "Limbah PT. Kahatex diduga cemari ratusan hektare sawah", SINDOnews, 2014, https://daerah.sindonews.com/read/861304/21/limbah-pt-kahatex-diduga-cemari-ratusan-hektare-sawah-1399456159, diakses tanggal 11 Juni 2020.

${ }^{10}$ Denny Kurniadi, “Walhi Jabar: Bau Banjir Rancaekek Mungkin Karena Limbah Pabrik”, Dara. co.id, 2020, https://www.dara.co.id/walhi-jabar-bau-banjir-rancaekek-mungkin-karena-limbah-pabrik.html, diakses tanggal 11 Juni 2020.

${ }^{11}$ Wini Elhetria Sayori, "Pencemaran Lingkungan Hidup Yang Dilakukan PT. Kahatex di Kabupaten Bandung Dihubungkan Dengan Undang-Undang Nomor 32 Tahun 2009 Tentang Perlindungan Dan Pengelolaan Lingkungan Hidup", Skripsi Fakultas Hukum Universitas Pasundan, 2017, hlm. 58.

${ }^{12}$ Wage Komarawidjaja, "Sebaran Limbah Cair Industri Tekstil Dan Dampaknya di Beberapa Desa Kecamatan Rancaekek Kabupaten Bandung", Jurnal Teknologi Lingkungan, Vol. 17, No 2, (2016), hlm. 119.

${ }^{13}$ Agus Rasyid C.W., "Pengawasan Izin Pembuangan Limbah Cair (IPLC) Perusahaan dalam Perlindungan Hak Konstitusional Masyarakat", Prosiding Seminar Nasional 2016 (Kerjasama Kementerian Lingkungan Hidup dan Kehutanan World Wide Fund (WWF)), 2016, hlm. 25. 
Penegakan Hukum Terhadap Pencemaran Lingkungan di Sungai Cikijing, Jawa Barat Akibat Aktivitas Industri Tekstil PT. Kahatex

alir sampai kepada Kabupaten Bandung yang merupakan daerah kabupaten lain.

Permasalahan atas tercemarnya lingkungan dari limbah tekstil PT. Kahatex ini sudah ada sejak tahun 1990-an. Namun, kasus tersebut memuncak pada tahun 2016 ketika Koalisi Melawan Limbah (KML) bertindak. ${ }^{14}$ Pada awalnya, dasar pembuangan limbah cair PT. Kahatex dijustifikasikan Surat Keputusan Bupati Sumedang nomor 660.31/Kep. 509-IPLC/ 2014 tentang Izin Pembuangan Limbah Cair (IPLC) ke Sungai Cikijing (SK Bupati). ${ }^{15}$ Atas kekhawatiran masyarakat yang memuncak, pada tahun 2016, SK Bupati tersebut dijadikan objek perkara di Pengadilan Tata Usaha (PTUN) Bandung oleh koalisi gabungan organisasi pemerhati lingkungan yang disebut dengan KML. ${ }^{16}$ Lewat kuasa hukumnya, PT. Kahatex membantah tudingan adanya pencemaran lingkungan dan te- lah dipenuhinya aturan yang berlaku. ${ }^{17}$ PTUN Bandung menyatakan bahwa surat Izin Pembuangan Limbah Cair (IPLC) tiga perusahaan, termasuk PT. Kahatex, untuk segera dicabut dalam Putusan No 178/G/2015/PTUN-BDG. ${ }^{18}$

Atas hal ini, PTUN Bandung telah memerintahkan Pemerintah Kabupaten (Pemkab) Sumedang mencabut IPLC perusahaan tersebut. ${ }^{19}$ Setelah itu, PT. Kahatex melakukan upaya banding, namun hasilnya tidak lah memuaskan bagi PT. Kahatex. ${ }^{20}$ Namun nyatanya, sampai pada tahap tersebut ketiga perusahaan masih beroperasi dan mengajukan langkah hukum hingga kasasi ke Mahkamah Agung (MA). Lagi-lagi, pada bulan Mei 2017, permohonan mereka tidak dikabulkan dengan dasar tidak adanya kesalahan dalam putusan sebelumnya, serta memerintahkan Pemkab Sumedang untuk mencabut IPLC perusahaan tersebut

${ }^{14}$ Yusuf Wijanarko, “[Laporan Khusus] Rancaekek dan Limbah yang Menyandera Sawah”, PikiranRakyatcom, https://www.pikiran-rakyat.com/bandung-raya/pr-01304488/laporan-khusus-rancaekek-dan-limbah-yang-menyandera-sawah?page=3, diakses tanggal 10 Juni 2020.

${ }^{15}$ Indonesia (b), Bupati Sumedang, Surat Keputusan tentang Izin Pembuangan Limbah Cair (IPLC) ke Sungai Cikijing, SK Bupati Sumedang No. 660.31/Kep.509-IPLC/ 2014 tahun 2014.

${ }^{16}$ Dony Iqbal, "Bupati Sumedang Digugat Soal Limbah Cair Di Rancaekek. Ada Apa?", Mongabay, 2015, https://www.mongabay.co.id/2015/12/22/ bupati-sumedang-digugat-soal-limbah-cair-di-rancaekek-ada-apa/, diakses tanggal 11 Juni 2020.

${ }^{17}$ Anisyah Al Faqir, "Sungai Cikijing Tercemar, diduga berasal Dari PT. Kahatex", Merdeka.com, 2016, https://www.merdeka.com/peristiwa/sungai-cikijing-tercemar-diduga-berasal-dari-limbah-pt-kahatex.html, diakses tanggal 11 Juni 2020.

${ }^{18}$ Pengadilan Tata Usaha Negara Bandung, Putusan No 178/G/2015/PTUN-BDG, hlm. 248-249.

${ }^{19}$ Agus Yulianto, "PTUN Kabulkan Gugatan Warga Soal IMB Kahatex", 2014, https://republika. co.id/berita/koran/kabar-jabar/14/09/18/nc2z8912-ptun-kabulkan-gugatan-warga-soal-imb-kahatex, diakses tanggal 11 Juni 2020.

${ }^{20}$ Pitriyani Gunawan, "Kahatex, Pemkab Banding Putusan PTUN", Sumedang Online, 2016, https://www.sumedang.online/2016/06/kahatex-pemkab-banding-putusan-ptun/, diakses tanggal 11 Juni 2020. 
dalam putusan MA bernomor 187/K/ TUN/LH/2017. Pencabutan IPLC PT. Kahatex tersebut mengakibatkan perusahaan tidak lagi dapat melaksanakan aktivitas pembuangan limbah cair ke Sungai Cikijing.

Akan tetapi, faktanya setelah enam bulan dari putusan MA, PT. Kahatex mendapatkan kembali IPLC-nya. ${ }^{21}$ Pihak perusahaan bahkan mengatakan Pemkab Sumedang tidak pernah mencabut izin mereka. Dasar ketidakpastian pelaksanaan hukum ini ada pada masalah karyawan PT. Kahatex. Dengan dihentikannya kegiatan operasional perusahaan tersebut, maka puluhan ribu karyawan PT. Kahatex terancam dirumahkan atau bahkan di-PHK. ${ }^{22}$ Hal ini pun menyebabkan permasalahan antara penerapan hukum lingkungan Indonesia dengan ancaman nasib karyawan PT. Kahatex yang atas haknya untuk bekerja dan mendapatkan penghidupan yang layak. Ketakutan ini lah yang menjadi penghalang penegakan hukum lingkungan pada masalah pembuangan lingkungan PT. Kahatex. Oleh sebab itu, tulisan ini akan menganalisis permasalahan tersebut serta memberikan saran kepada Pemerintah untuk menanganinya.

\section{Peraturan Lingkungan Terkait Pem- buangan Limbah Cair di Indonesia}

Pasal 5 ayat (1) Undang-Undang Nomor 32 Tahun 2009 tentang Perlindungan dan Pengelolaan Lingkungan Hidup (UUPLH) mengatur bahwa "setiap orang mempunyai hak yang sama atas lingkungan hidup yang baik dan sehat". ${ }^{23}$ Di samping itu, Pasal 6 ayat (1) UUPLH mengatur kewajiban setiap orang untuk "memelihara kelestarian fungsi lingkungan hidup serta mencegah dan menanggulangi pencemaran dan perusakan lingkungan hidup". ${ }^{24}$ Berdasarkan Pasal 65 ayat (1) sampai dengan ayat (5) UUP$\mathrm{LH}^{25}$ dapat ditemukan hak-hak yang terdapat dalam bidang lingkungan hidup, yakni: ${ }^{26}$

1. hak atas lingkungan hidup yang baik dan,

${ }^{21}$ Nadia Astriani, Yulinda Adharani, "Fungsi Izin Dalam Pengendalian Pencemaran Lingkungan (Studi Kasus: Gugatan Penerbitan Izin Pembuangan Limbah Cair di Sungai Cikijing", Jurnal Hukum Lingkungan Indonesia, Vol. 03, No. 01, (2016), hlm. 124.

${ }^{22}$ Dhio Faiz, "Saat Kahatex 'Tantang' Bupati Sumedang Cabut Izin Limbah", CNN Indonesia, 2018, https://www.cnnindonesia.com/nasional/20180326204822-75-286090/saat-kahatex-tantang-bupati-sumedang-cabut-izin-limbah, diakses tanggal 11 Juni 2020.

${ }^{23}$ Indonesia (c), Undang-Undang tentang Perlindungan dan Pengelolaan Lingkungan Hidup, UU No. 32 Tahun 2009, LN No. 140 Tahun 2009, TLN No. 5059, ps. 5 ayat (2).

${ }^{24}$ Ibid., Ps. 6 ayat (1).

${ }^{25}$ Ibid., Ps. 65 ayat (1)-(5).

${ }^{26}$ Lihat juga Ashabul Kahpi, "Jaminan Konstitusional Terhadap Hak Atas Lingkungan Hidup di Indonesia", Al Daulah: Jurnal Hukum Pidana dan Ketatanegaraan, Vol. 2, No. 2, (2013), hlm.149. 
Penegakan Hukum Terhadap Pencemaran Lingkungan di Sungai Cikijing, Jawa Barat Akibat Aktivitas Industri Tekstil PT. Kahatex

2. hak mendapatkan pendidikan lingkungan hidup,

3. hak untuk mengakses informasi, akses partisipasi dan akses keadilan dalam memenuhi hak atas lingkungan hidup yang baik dan sehat,

4. hak mengajukan usul dan/atau keberatan terhadap rencana usaha dan/atau kegiatan yang diperkirakan dapat menimbulkan dampak terhadap lingkungan hidup,

5. hak untuk berperan dalam perlindungan dan pengelolaan lingkungan hidup, dan

6. hak melakukan pengaduan akibat dugaan pencemaran dan/ atau perusakan lingkungan hidup.

Sebagai pemenuhan hak-hak tersebut, di dalam hukum lingkungan dikenal dengan kewajiban prosedural yang harus dipenuhi pihak-pihak yang kegiatannya akan berdampak pada lingkungan. Hal ini berbentuk perizinan yang fungsinya bermacam-macam sesuai dengan kegiatan yang ingin dilakukan. Pasal 1 angka 19 Undang-Undang Nomor 30 Tahun 2014 Tentang Administrasi
Pemerintahan mengartikan izin sebagai "Keputusan Pejabat Pemerintahan yang berwenang sebagai wujud persetujuan atas permohonan Warga Masyarakat sesuai dengan ketentuan peraturan perundang-undangan". ${ }^{27}$ Sementara itu, Pasal 1 angka 8 dan 9 Peraturan Menteri Dalam Negeri Nomor 24 Tahun 2006 tentang Pedoman Penyelenggaraan Terpadu Satu Pintu menyatakan bahwa ${ }^{28}$

"izin adalah dokumen yang dikeluarkan oleh pemerintah daerah berdasarkan peraturan daerah atau peraturan lainnya yang merupakan bukti legalitas, menyatakan sah atau diperbolehkannya seseorang atau badan untuk melakukan usaha atau kegiatan tertentu."

Oleh karena itu, izin bukanlah semata-mata persyaratan administratif yang tidak menyebabkan konsekuensi apapun, melainkan merupakan hal penting dalam penegakan hukum lingkungan dengan fungsi menjadi alat pengendali aktivitas masyarakat untuk memastikan kelestarian lingkungan hidup. ${ }^{29}$

Perizinan untuk pembuangan air limbah ke sumber air sendiri merupakan suatu bentuk instrumen pencegahan pencemaran dan/ atau kerusakan lingkungan hidup yang diatur di dalam Pa-

\footnotetext{
${ }^{27}$ Indonesia (d), Undang-Undang tentang Administrasi Pemerintahan, UU Nomor 30 Tahun 2014, LN No. 292 Tahun 2014, TLN No. 5601, Ps. 1 angka (19).

${ }^{28}$ Indonesia (e), Menteri Dalam Negeri, Peraturan Menteri Dalam Negeri tentang Pedoman Penyelenggaraan Terpadu Satu Pintu, Permendagri No. 24 Tahun 2006, ps.1 angka (8) dan (9).

${ }^{29}$ N. M. Spelt dan J.B.J. M ten Berge, Pengantar Hukum Perizinan, (Surabaya: Penerbit Yuridika, 1993), hlm. 2-3.
} 
sal 14 UUPPLH. ${ }^{30}$ Berdasarkan Pasal 48 ayat (2) Peraturan Pemerintah Nomor 27 Tahun 2012 tentang Izin Lingkungan, dikatakan bahwa pemrakarsa wajib untuk memiliki izin Pembuangan Limbah Cair atau yang selanjutnya disebut dengan IPLC. ${ }^{31}$ Pengertian IPLC jika dikaitkan dengan Pasal 20 ayat (3) UUPLH merupakan izin dari pemerintah kepada perusahaan untuk melakukan pembuangan limbah ke sumber air yang telah disediakan sebelumnya oleh pemerintah daerah atau sumber air yang berada di bawah pengawasan pemerintah daerah. ${ }^{32}$ Secara spesifik, izin IPLC diatur pada Peraturan Pemerintah (PP) Nomor 82 Tahun 2001 tentang Pengelolaan Kualitas Air dan Pengendalian Pencemaran Air (PP No. 82 Tahun 2001) yang menyatakan bahwa setiap penanggung jawab usaha dan/atau kegiatan yang membuang air limbah ke air atau sumber air wajib mencegah dan menanggulangi terjadinya pencemaran air dan setiap penanggung jawab usaha dan/atau kegiatan yang membuang air limbah ke air atau sumber air wajib menaati persyaratan yang ditetapkan dalam izin. $^{33}$ Jangka waktu berlakunya IPLC adalah selama 5 tahun dan pemegang izin harus melakukan daftar ulang per 1 tahun sekali. ${ }^{34}$

Adapun persyaratan administrasi yang harus dipenuhi dalam permohonan izin pembuangan air limbah berkaitan dengan syarat jenis dan prosedur pembuangan air limbah ke media lingkungan, kewajiban untuk mengolah limbah dan memantau dan melaporkan kewajiban, serta larangan yang dapat menyebabkan tercemarnya lingkungan berdasarkan standar yang ditetapkan, seperti dari baku mutu lingkungan. ${ }^{35}$ Pasal 1 ayat 9 PP No. 82 Tahun 2001 mendefinisikan baku mutu lingkungan sebagai "ukuran batas atau kadar makhluk hidup, zat, energi atau komponen yang ada atau harus ada dan atau unsur pencemar yang ditenggang keberadaannya dalam air". ${ }^{36}$ Baku mutu merupakan instrumen teknis untuk menentukan terjadinya pencemaran lingkungan hidup akibat pelaksanaan suatu izin usaha dan/ atau kegiatan sehingga sangat penting dalam kegiatan industri yang menghasilkan limbah.

\footnotetext{
${ }^{30}$ Lihat Indonesia (c), Op.Cit., Ps. 14.

${ }^{31}$ Indonesia (f), Pemerintah Pusat, Peraturan Pemerintah tentang Izin Lingkungan, PP No. 27 Tahun 2012, LN. 2012 No.48, TLN No. 5285, Ps. 48 ayat (2).

${ }^{32}$ Indonesia (c), Op.Cit., Ps. 20 ayat (3). Lihat juga Agus Rasyid C.W., Op.Cit., hlm. 27.

${ }^{33}$ Indonesia (g), Pemerintah Pusat, Peraturan Pemerintah tentang Pengelolaan Kualitas Air dan Pengendalian Pencemaran Air, PP No. 82 Tahun 2001, LN. 2001 No. 153, TLN No. 4161, ps. 37. Lihat juga Agus Rasyid C.W., Op.Cit., hlm. 21.

${ }^{34}$ Nadia Astriani, Op.Cit., hlm. 124.

${ }^{35}$ Ibid., hlm. 118.

${ }^{36}$ Indonesia (g), Op.Cit., Ps. 1 ayat (9).
} 
Selain itu, dalam Pasal 37 PP No. 82 Tahun 2001, dikatakan bahwa penanggung jawab usaha atau kegiatan yang membuang air limbah ke air atau sumber air wajib mencegah dan menanggulangi terjadinya pencemaran air. ${ }^{37}$ Pasal $40 \mathrm{PP}$ tersebut juga menjelaskan bahwa untuk melakukan pembuangan air limbah ke air atau sumber air harus mendapatkan izin tertulis dari Bupati atau Walikota. ${ }^{38}$ Untuk mendapatkan izin ini, pemrakarsa harus terlebih dahulu melakukan kajian pembuangan air limbah ke air terkait dengan data hasil pengaruh pembuangan limbah terhadap hewan dan tanaman, kualitas tanah dan air, serta kesehatan masyarakat.

Dalam memastikan penaatan setelah diberikannya izin, Bupati atau Walikota juga diwajibkan pada Pasal 44 ayat (1) PP No. 82 Tahun 2001 untuk melakukan pengawasan untuk memastikan ditaatinya persyaratan yang dicantumkan dalam izin yang diberikan ke perusahaan terkait. ${ }^{39} \mathrm{Hal}$ ini dapat dilaksanakan oleh pejabat pengawas lingkungan daerah. ${ }^{40}$ Adapun sanksi apabila melanggar ketentuan-ketentuan di dalam PP tersebut diatur pada Pasal 48 sampai dengan Pasal

\footnotetext{
${ }^{37}$ Ibid., ps. 37.

${ }^{38}$ Ibid., ps. 40.

${ }^{39}$ Ibid., Ps. 44 ayat (1).

${ }^{40}$ Ibid., Ps. 44 ayat (2).

${ }^{41}$ Ibid., Ps. 48-51.

${ }^{42}$ Indonesia (c), Op.Cit., Ps. 1 angka (14).

${ }^{43}$ Mahkamah Agung, Putusan No. 187/K/TUN/LH/2017, hlm. 14-25.
}

51 yang terdiri dari sanksi administrasi, ganti kerugian, dan sanksi pidana. ${ }^{41}$

\section{Uraian Permasalahan Penegakan Hukum pada Kasus PT. Kahatex}

Permasalahan hukum yang paling utama pada kasus ini adalah penegakan putusan PTUN yang telah menyatakan bahwa seharusnya IPLC PT. Kahatex dicabut, yang mengakibatkan harus diberhentikannya aktivitas PT. Kahatex yang menghasilkan limbah yang mencemari Sungai Cikijing. Pasal 1 angka 14 UUPLH menyatakan bahwa pencemaran lingkungan hidup terjadi ketika "masuk atau dimasukkannya makhluk hidup, zat, energi, dan/atau komponen lain ke dalam lingkungan hidup oleh kegiatan manusia sehingga melampaui baku mutu lingkungan hidup yang telah ditetapkan". ${ }^{42}$ Pada putusan MA bernomor 187/K/TUN/LH/2017, penggugat yang merupakan kumpulan organisasi pemerhati lingkungan telah memberikan bukti dalam bentuk tabel parameter baku mutu air kelas II dari tahun 2009 hingga tahun 2015..$^{43}$ Tabel tersebut telah menunjukkan bahwa pembuangan limbah pada Sungai Cikijing dari tahun ke tahun telah melampaui baku mutu. Hal 
ini juga dapat dilihat dengan mata telanjang di sekitar perairan Sungai Cikijing, dimana airnya berwarna keruh, berwarna coklat hingga hitam dan berbau. Limbah industri tekstil tergolong limbah cair dari proses pewarnaan yang merupakan senyawa kimia sintetis yang mempunyai kekuatan pencemar yang kuat dan mampu mencemari lingkungan. ${ }^{44}$

Atas adanya tuduhan tersebut, manajer umum PT. Kahatex, Luddy Sutedja dan manajer Instalasi Pengolahan Air Limbah (IPAL) PT. Kahatex menyangkal hal tersebut. Mereka berkata bahwa sejak dulu PT. Kahatex sudah selalu mengikuti peraturan pemerintah dengan menggunakan tiga unit instalasi IPAL dan tidak membuang limbah yang melebihi baku mutu yang ditetapkan pemerintah. Luddy Sutedja juga menambahkan bahwa bisa saja limbah yang mencemari Sungai Cikijing bukan limbah PT. Kahatex, melainkan industri-industri lain yang berada di lokasi yang tidak jauh dari perusahaan tersebut..$^{45}$ Akan tetapi, di tahun yang sama ketika pernyataan tersebut dipublikasikan, Wage Komarawidjaja menyimpulkan dalam penelitiannya bahwa limbah terbesar yang mencemari Sungai Cikijing adalah limbah cair industri teks- til yang belum diolah dengan sempurna. ${ }^{46}$ Sehingga hasil ini pun dapat menunjukkan bahwa limbah terbesar yang mencemari Sungai Cikijing berasal dari PT. Kahatex sendiri.

Oleh karena itu, putusan MA yang menyatakan bahwa sudah sepantasnya SK Bupati yang menjadi objek gugatan sudahlah tepat. Hal ini dikarenakan izin tersebut tidak lagi sesuai dengan kenyataan, dimana pembuangan limbah PT. Kahatex telah melampaui baku mutu dan menyebabkan pencemaran lingkungan yang telah dibuktikan oleh data lapangan. Akan tetapi, faktanya PT. Kahatex masih melaksanakan aktivitasnya

Mengikuti putusan MA, Robby Dewantara sebagai kepala Seksi Penataan Hukum Lingkungan Kabupaten Bandung mengatakan bahwa Bupati memang telah mencabut surat IPLC PT. Kahatex. Akan tetapi, tidak lama kemudian, surat izin yang baru diterbitkan lagi. Penerbitan surat izin yang baru ini pun tidak diikuti oleh langkah-langkah untuk menyesuaikan penerbitan limbah cair PT. Kahatex. ${ }^{47}$

Hal ini juga dikonfirmasi oleh Pemkab Sumedang, dimana penerbitan tersebut dilakukan oleh Dinas Penanaman

${ }^{44}$ Haryono et. al, "Pengolahan Limbah Zat Warna Tekstil Terdispersi dengan Metode Elektroflotasi", EduChemia (Jurnal Kimia dan Pendidikan), Vol.3, No.1, (2018), hlm. 95.

45 "Menjawab Keraguan IPAL Kahatex", Kahatex Peduli, 2016, www.kahatexpeduli.com /utama/menjawab-keraguan-ipal-kahatex, diakses tanggal 11 Juni 2020.

${ }^{46}$ Wage Komarawidjaja, Op.Cit., hlm. 124.

${ }^{47}$ Wawancara dengan Robby Dewantara, S.H., M.Si, Kepala Seksi Penataan Hukum Lingkungan/ PPNS LH Dinas Lingkungan Hidup Kabupaten Bandung pada 30 November 2019. 
Modal dan Pelayanan Terpadu Satu Pintu (DPMPTSP) berdasarkan rekomendasi teknis dari Dinas Lingkungan Hidup dan Kehutanan (DLHK). Penerbitan kembali tersebut didasari oleh hasil pengujian limbah bulanan yang masuk ke DLHK, hasil pemeriksaan kondisi IPAL di lapangan, serta dokumen dampak pembuangan limbah. Kepala DLHK Kabupaten Sumedang juga menambahkan, bahwa kekalahan PT Kahatex di MA pada saat itu dikarenakan PT. Kahatex belum melengkapi dokumen pengkajian pembuangan air limbah, yang mana telah dipenuhi saat penerbitan IPLC baru. ${ }^{48}$

Di sisi lain, Luddy Sutedja justru mengatakan bahwa Bupati Sumedang tidak pernah mencabut izin sama sekali dikarenakan "takut" apabila karyawan PT. Kahatex yang tidak bisa bekerja akan menyerang Kabupaten Sumedang. ${ }^{49} \mathrm{Hal}$ ini pun menunjukkan adanya ketidakpastian dari sisi Pemkab Sumedang.

\section{Langkah-langkah yang Harus Di- laksanakan Pemerintah dalam Me- negakkan Hukum Lingkungan Ter- kait Kasus PT. Kahatex}

Berdasarkan analisis di atas, setidaknya ada tiga masalah utama yang ada dalam kasus ini. Pertama, penegakan hukum mengenai pencemaran lingkungan yang diakibatkan oleh limbah tekstil PT. Kahatex di Sungai Cikijing; kedua, memastikan hak karyawan PT. Kahatex yang terancam apabila aktivitas PT. Kahatex diberhentikan; dan ketiga, memastikan kembalinya fungsi lingkungan yang tercemar agar dapat dipergunakan kembali secara layak oleh masyarakat. Berikut adalah langkah-langkah yang dapat dilakukan pemerintah dalam menyelesaikan permasalahan tersebut.

\section{A. Pelaksanaan Putusan MA}

Dikarenakan MA telah menguatkan bahwa pencabutan IPLC PT. Kahatex merupakan langkah yang sudah tepat karena adanya indikasi pencemaran lingkungan, sehingga sudah seharusnya pemerintah daerah mencabut IPLC tersebut. Pencabutan izin ini merupakan bagian dari sanksi administrasi yang ditujukan sebagai bentuk pemulihan keadaan ketika pemegang izin tidak melakukan tindakan yang disyaratkan dalam izin

\footnotetext{
${ }^{48}$ Tim Pikiran Rakyat, "[Laporan Khusus] Rancaekek dan Limbah yang Menyandera Sawah", PikiranRakyatcom, 2018, https://www.pikiran-rakyat.com/bandung-raya/pr-01304488/laporan-khusus-rancaekek-dan-limbah-yang-menyandera-sawah?page=4, diakses 20 September 2020.

${ }^{49}$ Dhio Faiz, Op.Cit.
} 
tersebut. ${ }^{50}$ Selaku pejabat TUN, pelaksanaan putusan ini merupakan salah satu kewajiban yang wajib dilaksanakan Bupati Sumedang yang diatur dalam Pasal 97 ayat (8) dan ayat (9) Undang-Undang Nomor 5 Tahun 1986 Tentang Peradilan Tata Usaha Negara (UU PTUN). Pasal tersebut menyatakan bahwa pembatalan atau tidak sahnya suatu Keputusan Tata Usaha Negara (KPTUN) oleh PTUN harus diikuti oleh keputusan pejabat TUN untuk mencabut KPTUN terkait. ${ }^{51}$ Selain itu, pejabat TUN juga diwajibkan untuk menerbitkan KPTUN yang baru. Ada pun sanksi yang dapat diberikan bagi tidak dijalankannya putusan adalah sanksi administratif dari atasan pejabat TUN yang bersangkutan, melalui pengumuman media massa, atau pengenaan uang paksa. $^{52}$

Apabila IPLC ini akan diterbitkan kembali, maka penerbitan tersebut pun seharusnya diikuti dengan penyesuaian yang efektif agar pencemaran tidak terjadi lagi. Hal ini sangat penting, karena dikuatkannya pencabutan SK Bupati bukan hanya karena cacat prosedur penerbitan, melainkan dilanggarnya peraturan yang menjadi syarat utama pemberian IPLC, yakni telah tercemarnya air Sungai Cikijing yang dibuktikan oleh hasil uji baku mutu air dan tampilan fisik sungai yang telah berwarna dan berbau. ${ }^{53}$ Sayangnya, PT. Kahatex tidak menunjukkan adanya upaya membenahi IPAL-nya untuk mengikuti putusan MA tersebut, melainkan tetap bersikukuh taatnya mereka terhadap peraturan yang berlaku. Oleh karena itu, Pemkab Sumedang seharusnya melaksanakan putusan MA dengan diikuti oleh tindakan lanjutan untuk membenahi pelanggaran yang ada.

\section{B. Pembuatan IPAL Terpadu}

Apabila putusan MA telah dilaksanakan dengan baik, upaya penyesuaian yang dapat dilakukan oleh Bupati Sumedang adalah dengan membuat IPAL Terpadu terlebih dahulu sebelum kemudian boleh menerbitkan kembali izin yang baru. Hal ini merupakan salah satu gagasan yang diungkapkan oleh Robby Dewantara yang akan dilaksanakan pihak Dinas Lingkungan Hidup Kabupaten Bandung dengan pemerintah daerah terkait. IPAL Terpadu merupakan sistem pengolahan air limbah yang dilakukan secara terpusat, bukan di masing-masing daerah secara terpisah, dengan bangun-

\footnotetext{
${ }^{50}$ Andri Gunawan Wibisana, “Tentang Ekor yang Tak Lagi Beracun: Kritik Konseptual atas Sanksi Administratif dalam Hukum Lingkungan di Indonesia”, Jurnal Hukum Lingkungan Indonesia, Vol. 6, No. 1, (2019), hlm. 59.

${ }^{51}$ Lihat Indonesia (h), Undang-Undang tentang Peradilan Tata Usaha Negara, UU No. 5 Tahun 1986, LN. 1986/ No.77, TLN No. 3344, ps. 97 ayat (8) dan (9).

${ }^{52}$ Putri Kemala Sari, “Penerapan Upaya Paksa dalam Eksekusi Putusan Pengadilan Tata Usaha Negara Kepada Pejabat Tata Usaha Negara", Jurnal Ius Civile, Vol. 1, No. 1, 2017, hlm. 30.

${ }^{53}$ Nadia Astriani, Op.Cit., hlm. 124.
} 
an yang digunakan untuk memproses limbah cair domestik yang difungsikan sesuai dengan baku mutu lingkungan agar hasil data yang dikeluarkan lebih akurat. $^{54}$

Pentingnya pembuatan IPAL Terpadu dikarenakan Sungai Cikijing mengalir antar dua kabupaten, sehingga IPAL yang dikelola sendiri oleh PT. Kahatex atau dipantau oleh satu pemerintah daerah saja tidak akan dapat merealisasikan penegakan hukum lingkungan yang baik. Adanya pengurus IPAL yang terpisah-pisah dapat juga mempengaruhi hasil laporan berkala terkait IPAL, dan laporan yang dilakukan oleh pihak PT. Kahatex sendiri juga berpotensi menjadi sangat subjektif. Hal ini terbukti dengan adanya perbedaan antara laporan dari pihak PT. Kahatex dengan pihak penggugat pada PTUN yang merupakan organisasi pemerhati lingkungan. Sehingga, dengan adanya IPAL Terpa$\mathrm{du}$, diharapkan hasil pemeriksaan baku mutu dari limbah cair PT. Kahatex di Sungai Cikijing dapat lebih objektif. Oleh karena itu, pembuatan IPAL Terpadu oleh pemerintah Provinsi Jawa Barat de- ngan melibatkan Pemkab Sumedang dan Kabupaten Bandung seharusnya segera direalisasikan. ${ }^{55}$

\section{Memastikan Hak Karyawan PT. Ka- hatex Apabila IPLC PT. Kahatex Di- cabut}

Salah satu masalah yang menghambat Bupati Sumedang untuk secara tegas menegakkan putusan PTUN terkait dicabutnya IPLC PT. Kahatex adalah, terancamnya hak untuk bekerja karyawan PT. Kahatex. ${ }^{56}$ Akan tetapi, seharusnya ini tidak menjadi permasalahan yang besar untuk penegakkan putusan PTUN. Hal ini dikarenakan jenis kegiatan industri yang ada pada PT. Kahatex tidak hanya berkaitan dengan tekstil, melainkan juga memproduksi poliester, serat poliester, dan benang. ${ }^{57}$ Sementara, hasil penelitian menunjukan bahwa sumber bahan pencemar berasal dari zat pewarna pakaian atau senyawa azo. ${ }^{58}$ Sehingga, apabila kegiatan terkait penyebab bahan pencemar tersebut dihentikan sementara untuk menunggu penyesuaian terhadap IPAL dilaksanakan, masih terdapat kegiatan lain di dalam PT. Kahatex yang dapat

\footnotetext{
${ }^{54}$ Mary Selintung, Mukhsan Putra Hatta, Akhmad Ikramuddin, “Evaluasi Sistem Instalasi Pengolahan Air Limbah (IPAL) Komunal Berbasis Masyarakat Di Kecamatan Rappocini Kota Makassar", 2015, hlm. 2.

${ }^{55}$ Fira Nursyabani, "Kabupaten Bandung Siap Bangun IPAL Terpadu di 3 Titik", Ayo Bandung, 2020, https://ayobandung.com/read/2020/03/09/81922/kabupaten-bandung-siap-bangun-ipal-terpadu-di-3-titik, diakses pada 19 September 2020.

${ }^{56}$ Dhio Faiz, Op.Cit.

57 "Tentang PT. KAHATEX", Dinas Tenaga Kerja Kota Cimahi, https://silima.cimahikota.go.id /p/pt-kahatex/\#, diakses tanggal 12 Juni 2020.

${ }^{58}$ Wage Komarawidjaja, Op.Cit., hlm. 124.
} 
dioperasikan sepanjang mengikuti peraturan yang terkait. Dalam hal ini, perusahaan dapat mengalokasikan pegawainya ke sektor kegiatan lain.

Hal ini sejalan dengan amanat pada Pasal 151 ayat (1) Undang-Undang Nomor 13 Tahun 2003 tentang Ketenagakerjaan yang mewajibkan pihak pengusaha, pekerja/buruh, serikat pekerja/serikat buruh, dan pemerintah, dengan segala upaya harus mengusahakan agar jangan terjadi pemutusan hubungan kerja $(\mathrm{PH}-$ K). ${ }^{59}$ Dalam Surat Edaran (SE) Menteri Tenaga Kerja Kepada Pimpinan Perusahaan di Seluruh Indonesia No. SE-907/ MEN/PHI-PPHI/X/2004 tentang Pencegahan Pemutusan Hubungan Kerja Massal, upaya pencegahan PHK ini terdiri dari: $:^{60}$

a. mengurangi upah dan fasilitas pekerja tingkat atas, misalnya tingkat manajer dan direktur;

b. mengurangi sif;

c. membatasi/menghapuskan kerja lembur;

d. mengurangi jam kerja;

e. mengurangi hari kerja;

f. meliburkan atau merumahkan pekerja/buruh secara bergilir untuk sementara waktu; g. tidak atau memperpanjang kontrak bagi pekerja yang sudah habis masa kontraknya;

h. memberikan pensiun bagi yang sudah memenuhi syarat.

Apabila terdapat karyawan yang harus dirumahkan, maka perusahaan juga harus memastikan pemenuhan hak-hak mereka yang diatur pada peraturan perundang-undangan Indonesia. Hal ini secara khusus diatur pada SE Menteri Tenaga Kerja No. SE-05/M/BW/1998 Tahun 1998 tentang Upah Pekerja yang Dirumahkan Bukan ke Arah Pemutusan Hubungan Kerja telah menjelaskan bahwa pengusaha diwajibkan membayar penuh upah karyawan, atau membayar tidak secara penuh dengan syarat kesepakatan antara perusahaan dengan serikat pekerja atau pekerjanya. ${ }^{61}$ Selain itu, di sini andil dari Bupati Sumedang sebagai pemerintah daerah dibutuhkan untuk memberikan solusi bagi pengalokasian karyawan suatu perusahaan ke pekerjaan lain, apabila dibutuhkan.

Akan tetapi hal ini tidak dilakukan PT. Kahatex, dengan alasan bahwa dicabutnya izin berdampak pula terhadap orderan produk PT. Kahatex yang mengancam keseluruhan operasi PT. Kahatex

${ }^{59}$ Indonesia (i), Undang-Undang tentang Ketenagakerjaan, UU No. 13 Tahun 2003, LN.2003/ NO.39, TLN No. 4279, ps. 151 ayat (1).

${ }^{60}$ Indonesia (j), Menteri Tenaga Kerja, Surat Edaran Menteri Tenaga Kerja tentang Pencegahan Pemutusan Hubungan Kerja Massal, SE Menaker No. SE-907/MEN/PHI-PPHI/X/2004 tahun 2004.

${ }^{61}$ Indonesia (k), Menteri Tenaga Kerja, Surat Edaran Menteri tenaga Kerja tentang Upah Pekerja yang Dirumahkan Bukan ke Arah Pemutusan Hubungan Kerja. No. SE-05/M/BW/1998 Tahun 1998. 
Penegakan Hukum Terhadap Pencemaran Lingkungan di Sungai Cikijing, Jawa Barat Akibat Aktivitas Industri Tekstil PT. Kahatex

tersebut. ${ }^{22}$ Oleh karena itu, jalan yang ditempuh PT. Kahatex ialah segera mendaftarkan ulang izin ketika penguatan pencabutan izin yang lama oleh MA dengan satu persyaratan tambahan tanpa memperbaiki IPAL mereka. ${ }^{63} \mathrm{Hal}$ ini tentunya sangat disayangkan, mengingat bahwa sudah kewajiban suatu perusahaan untuk memenuhi persyaratan izin lingkungannya beserta memperhatikan kondisi pekerjanya, tanpa harus mengorbankan satu daripada yang lain.

\section{Pemulihan Lahan Pertanian Tercemar}

Selain masalah penegakan hukum dan pemastian hak karyawan, masalah lain yang diakibatkan dari oleh pencemaran masif ini adalah kerusakan lahan pertanian di sepanjang Sungai Cikijing. Adanya pencemaran lingkungan di Sungai Cikijing dapat diindikasikan dengan menurunnya kualitas lahan pertanian dan menyebabkan menurunnya produksi, bahkan menyebabkan kematian tanaman padi atau bulir padinya hampa dan ikan yang dibudidayakan mati. ${ }^{64}$ Lahan pertanian yang rusak dan tercemar akibat limbah industri juga menjadi keluh kesah petani di Rancaekek. Berdasarkan penelitian Greenpeace Asia Tenggara dan Walhi Jabar 2015 di daerah tersebut, terdapat pencemaran sawah seluas 1.215 hektar dan bertambah 727 hektar saat banjir. Hal ini menyebabkan produktivitas sawah menurun 1-1,5 ton per hektar tiap musim. Kerugian yang diakibatkan mencapai Rp3,65 miliar per tahun. ${ }^{65}$ Oleh karena itu selain menegakan hukum, pemerintah juga wajib memastikan kembalinya daerah sekitar Sungai Cikijing pada kondisi dan fungsi semula agar dapat dipergunakan dengan layak oleh masyarakat.

Atas hal ini, pemerintah Rancaekek sempat mewacanakan akan membeli lahan produktif yang terpapar limbah B3 tersebut dan dialihfungsikan. Namun, rencana tersebut tidaklah menyelesaikan masalah yang ada. ${ }^{66}$ Alih fungsi sawah menjadi kawasan industri bukanlah solusi yang tepat terhadap pencemaran lingkungan, dan tidak sesuai dengan semangat pemerintah untuk mewujudkan

${ }^{62}$ Yedi Supriadi, “63 Ribu Karyawan Kahatex Terancam Dirumahkan” Pikiran Rakyat, 2016, https://www.pikiran-rakyat.com/bandung-raya/pr-01261282/63-ribu-karyawan-kahatex-terancam-dirumahkan-376101, diakses tanggal 7 Oktober 2020.

${ }^{63}$ Tim Pikiran Rakyat, Op.Cit.

${ }^{64}$ Indriyati Kamil, "Peran Komunikasi Pemerintahan dalam Penanganan Lingkungan Kumuh", Jurnal Komunikasi, Vol 11, No.1, (2018), hlm. 133.

${ }^{65}$ Indra Nugraha, "Sawah Tercemar Limbah Pabrik, Beginilah Nasib Petani Rancaekek", Mongabay, 2015, https://www.mongabay.co.id/2015/04/14/sawah-tercemar-limbah-pabrik-beginilah-nasib-petani-rancaekek/, diakses tanggal 28 Juli 2020.

${ }^{66}$ Ibid. 
swasembada pangan, dikarenakan banyaknya warga sekitar yang bergantung pada Sungai Cikijing sebagai sumber air untuk kehidupan sehari-hari mereka. ${ }^{67}$

Sebaiknya, pemerintah maupun PT. Kahatex membeli lahan warga tersebut dengan tujuan untuk dinormalisasi kembali. Pembelian lahan ini sebaiknya juga diikuti dengan pemberian kompensasi kepada warga sebagai akibat diambilnya sumber pencaharian sehari-hari mereka. Langkah awal untuk normalisasi dengan pembuatan IPAL Terpadu, sebagaimana telah dijelaskan dalam poin diatas, sehingga air untuk pengairan sawah bukan berasal dari air tercemar lagi. Kemudian, apabila lahan sawah ini sudah normal, maka PT. Kahatex bisa menjual kembali lahan tersebut baik kepada warga atau kepada pemerintah. Normalisasi ini diharapkan dapat menunjang kegiatan masyarakat dan memberikan dampak positif bagi masyarakat tersebut. ${ }^{68}$ Selain itu, pemerintah maupun masyarakat kemudian dapat melakukan usaha-usaha preventif untuk terulangnya pencemaran, seperti penggunaan teknologi untuk mengolah air limbah dengan polutan organik tinggi. ${ }^{69}$

\section{Penutup}

Hak atas lingkungan hidup yang baik dan sehat merupakan hak warga negara yang tercantum di dalam konstitusi Indonesia dan wajib dipenuhi oleh negara. Pencemaran lingkungan hidup yang mengakibatkan masyarakat tidak dapat beraktivitas sebagaimana seharusnya. Tantangan dalam pemenuhan hak ini timbul akibat kebutuhan negara untuk mengembangkan sektor industri dengan tujuan pembangunan, seperti yang terjadi dalam kasus pencemaran lingkungan di Sungai Cikijing akibat industri tekstil PT. Kahatex. Limbah yang dikeluarkan industri tersebut sangat berpotensi merusak lingkungan. Oleh karena itu sangat penting untuk menjaga batas baku mutu lingkungan agar masyarakat di Sungai Cikijing yang menggunakan sungai tersebut sebagai sarana memenuhi kebutuhan sehari-hari. Atas adanya bukti terlampauinya baku mutu lingkungan ini selama bertahun-tahun, maka sudah sepantasnya IPLC PT. Kahatex dicabut sebagaimana yang diperkuat oleh putusan MA, untuk kemudian dapat diterbitkan lagi ketika persyaratan izin telah sesuai dengan semestinya.

\footnotetext{
${ }^{67}$ Anggi Oktarinda, "Ironi dari Timur Bandung”, Bisnis.com, 2017, https://m.bisnis.com/amp/ read/20170605/430/659175/ironi-dari-timur-bandung, diakses pada 20 September 2020.

${ }^{68}$ Shinta Ayu Widyastuti, “Analisis Dampak Normalisasi Daerah Aliran Sungai (Das) Ciliwung Terhadap Masyarakat Kampung Pulo Di Dki Jakarta”, Departemen Ekonomi Sumberdaya Dan Lingkungan Fakultas Ekonomi Dan Manajemen Institut Pertanian Bogor Bogor, 2017, hlm. 24.

${ }^{69}$ Sri Moertinah,"Kajian Proses Anaerobik Sebagai Alternatif Teknologi Pengolahan Air Limbah Industri Organik Tinggi", Jurnal Riset Teknologi Pencegahan dan Pencemaran Industri, Vol. 1 No. 2, (2010), hlm. 113.
} 
Dalam rangka menegakkan hukum lingkungan, Pemkab Sumedang sudah seharusnya melarang kegiatan pembuangan limbah cair PT. Kahatex setelah putusan pengadilan, untuk kemudian sistem IPAL perusahaan tersebut dapat diperbaharui agar dapat kembali sesuai dengan standar yang ditetapkan oleh undang-undang. Selain itu, pemerintah dan PT. Kahatex wajib memperhatikan hak-hak karyawan mereka sesuai dengan peraturan perundang-undangan yang berlaku. Adapun kebijakan yang dapat dilaksanakan pemerintah dan PT. Kahatex dalam permasalahan ini adalah dengan berkoordinasi dalam mewujudkan IPAL Terpadu, mengalokasikan karyawan PT. Kahatex ke kegiatan industri lain selama proses pembuatan IPAL Terpadu dilaksanakan, dan upaya normalisasi lahan tercemar agar dapat digunakan kembali oleh masyarakat sekitar Sungai Cikijing. 


\section{DAFTAR PUSTAKA}

\section{Peraturan Perundang-Undangan}

Indonesia. Undang-Undang Dasar Negara Republik Indonesia Tahun 1945. . Undang-Undang tentang Peradilan Tata Usaha Negara. UU No. 5 Tahun 1986. LN. 1986/ No.77, TLN No. 3344.

- Undang-Undang tentang Ketenagakerjaan. UU No. 13 Tahun 2003. LN.2003/NO.39, TLN No. 4279.

- Undang-Undang tentang Perlindungan dan Pengelolaan Lingkungan Hidup. UU No. 32 Tahun 2009. LN No. 140 Tahun 2009. TLN No. 5059.

- Undang-Undang tentang Administrasi Pemerintahan. UU Nomor 30 Tahun 2014. LN No. 292 Tahun 2014. TLN No. 5601.

Pemerintah Pusat. Peraturan Pemerintah tentang Pengelolaan Kualitas Air dan Pengendalian Pencemaran Air. PP No. 82 Tahun 2001. LN. 2001 No. 153, TLN No. 4161.

- Pemerintah Pusat. Peraturan Pemerintah tentang Izin Lingkungan. PP No. 27 Tahun 2012. LN. 2012 No.48, TLN No. 5285.

Menteri Dalam Negeri. Peraturan Menteri Dalam Negeri tentang Pedoman Penyelenggaraan Terpadu
Satu Pintu. Permendagri No. 24 Tahun 2006.

Menteri Tenaga Kerja. Surat Edaran Menteri tenaga Kerja tentang Upah Pekerja yang Dirumahkan Bukan ke Arah Pemutusan Hubungan Kerja. SE Menaker No. SE-05/M/BW/1998 Tahun 1998.

Menteri Tenaga Kerja. Surat Edaran Menteri Tenaga Kerja tentang Pencegahan Pemutusan Hubungan Kerja Massal. SE Menaker No. SE-907/ MEN/PHI-PPHI/X/2004 tahun 2004.

Bupati Sumedang. Surat Keputusan tentang Izin Pembuangan Limbah Cair (IPLC) ke Sungai Cikijing. SK Bupati Sumedang No. 660.31/Kep. 509-IPLC/2014 tahun 2014.

\section{Putusan pengadilan}

Pengadilan Tata Usaha Negara Bandung, Putusan No 178/G/2015/PTUN-BDG.

Mahkamah Agung, Putusan No. 187/K/ TUN/LH/2017.

\section{Buku}

Darsono, Valentinus. Pengantar Ilmu Lingkungan. Yogyakarta: Universitas Atma Jaya Yogyakarta, 1995. 
Heldeweg, Michiel A. dan René J.H.G. Seerden. Environmental Law in the Netherlands. Alphen aan den Rijn: Wolters Kluwer, 2012.

Spelt, N. M. dan J.B.J. M ten Berge. Pengantar Hukum Perizinan. Surabaya: Penerbit Yuridika, 1993.

\section{Artikel Jurnal/Media Massa}

Ariefianto, Harry Agung. "Penerapan Sanksi Administrasi Pencemaran Lingkungan Hidup Akibat Kegiatan Industri (Studi Kasus Di CV. Slamet Widododi Semarang)", Unnes Law Journal, Vol. 4, No. 1, 2015.

Astriani, Nadia dan Yulinda Adharani. "Fungsi izin dalam Pengendalian Pencemaran lingkungan (Studi kasus: gugatan Penerbitan izin Pembuangan limbah cair di Sungai Cikijing)", Jurnal Hukum Lingkungan, Vol. 3, Issue 1, 2016.

Gregorius, Junior B. “Hak Asasi Manusia (HAM) Atas Lingkungan Hidup (Suatu Rekfleksi Sosio-Yuridis atas Implementasi Penyelesaian Sengketa Lingkungan)", Jurnal Hukum dan Pembangunan Tahun ke-39, No. 23, 2009.

Haryono, Muhammad Faizal D, dkk. "Pengolahan Limbah Zat Warna Tekstil Terdispersi dengan Metode Elektroflotasi", EduChemia (Jurnal Kimia dan Pendidikan), Vol.3, No.1, 2018.

Kahpi, Ashabul. "Jaminan Konstitusional Terhadap Hak Atas Lingkungan Hidup di Indonesia", Al Daulah: Jurnal Hukum Pidana dan Ketatanegaraan, Vol. 2, No. 2, 2013.
Komarawidjaja, Wage. "Sebaran Limbah Cair Industri Tekstil Dan Dampaknya di Beberapa Desa Kecamatan Rancaekek Kabupaten Bandung", Jurnal Teknologi Lingkungan, Vol. 17, No. 2, 2016.

Nuraeni, Yeni. “Dampak Perkembangan Industri Pertambangan Nikel Terhadap Kondisi Sosial, Ekonomi Dan Budaya Masyarakat", Seminar Nasional Edusainstek FMIPA UNIMUS, 2018.

Sari, Putri Kemala. "Penerapan Upaya Paksa dalam Eksekusi Putusan Pengadilan Tata Usaha Negara Kepada Pejabat Tata Usaha Negara", Jurnal Ius Civile, Vol. 1, No. 1, 2017.

Selintung, Mary. Mukhsan Putra Hatta, dan Akhmad Ikramuddin. "Evaluasi Sistem Instalasi Pengolahan Air Limbah (IPAL) Komunal Berbasis Masyarakat Di Kecamatan Rappocini Kota Makassar", 2015.

\section{Lain-Lain}

"Menjawab Keraguan IPAL Kahatex", Kahatex Peduli, 2016, www.kahatexpeduli.com/utama/menjawab-keraguan-ipal-kahatex, diakses tanggal 11 Juni 2020.

"Tentang PT. KAHATEX", Dinas Tenaga Kerja Kota Cimahi, https://silima. cimahikota.go.id/p/pt-kahatex/\#, diakses tanggal 12 Juni 2020.

"Wawancara dengan Robby Dewantara, S.H., M.Si.," Kepala Seksi Penataan Hukum Lingkungan/ PPNS LH Dinas Lingkungan Hidup Kabupaten Bandung pada 30 November 2019. 
C.W., Agus Rasyid. "Pengawasan Izin Pembuangan Limbah Cair (IPLC) Perusahaan dalam Perlindungan Hak Konstitusional Masyarakat", Prosiding Seminar Nasional 2016 (Kerjasama Kementerian Lingkungan Hidup dan Kehutanan World Wide Fund (WWF)), 2016.

Faiz, Dhio. "Saat Kahatex 'Tantang' Bupati Sumedang Cabut Izin Limbah", CNN Indonesia, 2018, https:// www. cnnindonesia.com/nasional/20180326204822 -75-286090/saat-kahatex-tantang-bupati-sumedang-cabut-izin-limbah, diakses tanggal 11 Juni 2020.

Faqir, Anisyah Al. "Sungai Cikijing Tercemar, diduga berasal Dari PT. Kahatex", Merdeka.com, 2016, https:// www.merdeka.com/peristiwa/sungai-cikijing-tercemar-diduga-berasal-dari-limbah-pt-kahatex.html, diakses tanggal 11 Juni 2020.

Gunawan, Pitriyani. "Kahatex, Pemkab Banding Putusan PTUN", Sumedang Online, 2016, https://www.sumedang.online/2016/06/kahatex-pemkab-banding-putusan-ptun/, diakses tanggal 11 Juni 2020.

Iqbal, Dony. "Bupati Sumedang Digugat Soal Limbah Cair Di Rancaekek. Ada Apa?", Mongabay, 2015, https:// www.mongabay.co.id/2015/12/22/ bupati-sumedang-digugat-soal-limbah-cair-di-rancaekek-ada-apa/, diakses tanggal 11 Juni 2020.

Kamil, Indriyati. "Peran Komunikasi Pemerintahan dalam Penanganan Lingkungan Kumuh", Jurnal Komunikasi,
Vol. 11, No. 1, 2018.

Kurniadi, Denny. “Walhi Jabar: Bau Banjir Rancaekek Mungkin Karena Limbah Pabrik", Dara.co.id, 2020, https://www.dara.co.id/walhi-jabar-bau-banjir-rancaekek-mungkin-karena-limbah-pabrik.html, diakses tanggal 11 Juni 2020.

Moertinah, Sri. "Kajian Proses Anaerobik Sebagai Alternatif Teknologi Pengolahan Air Limbah Industri Organik Tinggi", Jurnal Riset Teknologi Pencegahan dan Pencemaran Industri, Vol. 1 No. 2, 2010.

Nashear, Dila. "Limbah PT. Kahatex diduga cemari ratusan hektare sawah", SINDOnews, 2014, https://daerah. sindonews.com/read/861304/21/ limbah-pt-kahatex-diduga-cemari-ratusan-hektare-sawah-1399456159, diakses tanggal 11 Juni 2020.

Nugraha,Indra.“SawahTercemarLimbah Pabrik, Beginilah Nasib Petani Rancaekek", Mongabay, 2015, https:// www.mongabay.co.id/2015/04/14/ sawah-tercemar-limbah-pabrik-beginilah-nasib-petani-rancaekek/, diakses tanggal 28 Juli 2020.

Nursyabani, Fira. "Kabupaten Bandung Siap Bangun IPAL Terpadu di 3 Titik", Ayo Bandung, 2020, https://ayobandung. $\mathrm{com} / \mathrm{read} / 2020 / 03 / 09 / 81922$ / kabupaten-bandung-siap-bangun-ipal-terpadu-di-3-titik, diakses pada 19 September 2020.

Oktarinda, Anggi. "Ironi dari Timur Bandung", Bisnis.com, 2017, https://m.bisnis.com/amp/ 
Penegakan Hukum Terhadap Pencemaran Lingkungan di Sungai Cikijing, Jawa Barat Akibat Aktivitas Industri Tekstil PT. Kahatex

$\mathrm{read} / 20170605 / 430 / 659175 /$ ironi-dari-timur-bandung, diakses pada 20 September 2020.

Putri, Restu Diantina. "11 Perusahaan Perusak Lingkungan Rugikan Negara Rp18 Triliun Baca selengkapnya di artikel "11 Perusahaan Perusak Lingkungan Rugikan Negara Rp18 Triliun", Tirto.id, 2019, https:/ / tirto. id/dgZ6"https://tirto.id/11-perusahaan-perusak-lingkungan-rugikan-negara-rp18-triliun-dgZ6, diakses tanggal 6 Oktober 2020.

Ridwan, Ita Rustiati. "Dampak Industri Terhadap Lingkungan Dan Sosial", Jurnal Geografi Gea, Vol. 7, No. 2, 2010.

Sayori, Wini Elhetria. "Pencemaran Lingkungan Hidup Yang Dilakukan PT. Kahatex di Kabupaten Bandung Dihubungkan Dengan Undang-Undang Nomor 32 Tahun 2009 Tentang Perlindungan Dan Pengelolaan Lingkungan Hidup", Skripsi (S1) thesis, Fakultas Hukum Universitas Pasundan, 2017.

Supriadi, Yedi. “63 Ribu Karyawan Kahatex Terancam Dirumahkan" Pikiran Rakyat, 2016, https://www. pikiran-rakyat.com/bandung-raya/ pr-01261282/63-ribu-karyawan-kahatex-terancam-dirumahkan-376101, diakses tanggal 7 Oktober 2020.

Tim Pikiran Rakyat. "[Laporan Khusus] Rancaekek dan Limbah yang Menyandera Sawah", PikiranRakyatcom, 2018, https:// www.pikiran-rakyat.com/ bandung-raya / pr-01304488/la- poran-khusus-rancaekek-dan-limbah-yang-menyandera-sawah?page $=4$, diakses 20 September 2020 .

Widyastuti, Shinta Ayu. "Analisis Dampak Normalisasi Daerah Aliran Sungai (Das) Ciliwung Terhadap Masyarakat Kampung Pulo Di Dki Jakarta", Departemen Ekonomi Sumberdaya Dan Lingkungan Fakultas Ekonomi Dan Manajemen Institut Pertanian Bogor Bogor, 2017.

Wijanarko, Yusuf. "[Laporan Khusus] Rancaekek dan Limbah yang Menyandera Sawah", PikiranRakyatcom, https://www.pikiran-rakyat. com/bandung-raya/pr-01304488/ laporan-khusus-rancaekek-dan-limbah-yang-menyandera-sawah?page=3, diakses tanggal 10 Juni 2020 .

Yasin, Muhammad, "Masalah Eksekusi Paksa Putusan PTUN", Hukum Online, 2013, https:// www.hukumonline.com/ klinik/detail/ulasan/lt5206db0fe23 $9 \mathrm{e} / \mathrm{masalah-eksekusi-paksa-}$ -putusan-ptun/, diakses tanggal 12 Juni 2020.

Yulianto, Agus, "PTUN Kabulkan Gugatan Warga Soal IMB Kahatex", 2014, https://republika.co.id/berita/koran/kabar-jabar/14/09/18/ nc2z8912-ptun-kabulkan-gugatan-warga-soal-imb-kahatex 